\title{
Studies on the Polymerization of Acrolein Oxime. XI. Equimolar Reaction of Acrolein Oxime and Butyllithium
}

\author{
Tadatoshi OtA, ${ }^{*}$ Masami TAnAKA, ${ }^{* *}$ Yutaka AsAhI, ${ }^{* *}$ \\ and Seizo MASUDA* \\ *Department of Applied Chemistry, Faculty of Engineering, \\ Tokushima University, Tokushima 770, Japan. \\ **Faculty of Pharmaceutical Science, Tokushima University of Arts and Science, \\ Tokushima 770, Japan.
}

(Received June 21, 1979)

\begin{abstract}
An equimolar reaction of acrolein oxime (AOM) and butyllithium (BuLi) was studied at $0^{\circ} \mathrm{C}$ in different solvents. The structure of the reaction products was determined by ${ }^{13} \mathrm{C}$ NMR spectroscopy and gas chromatography-mass spectrometry. Lithium acrolein oxime was formed as the main product. When the reaction mixture was treated with dilute hydrochloric acid, about $80 \%$ of the AOM was recovered and many other products, such as heptanal oxime, 2methylhexanal oxime, butyl vinyl ketone oxime etc., were obtained in different yields depending on the kind of solvent used; BuLi can add to the head or tail of the vinyl group and to the oxime group, of AOM. The initial processes of $\mathrm{AOM}$ polymerization by $\mathrm{BuLi}$ are explained on the basis of the reaction products.

KEY WORDS Acrolein Oxime / Butyllithium / Equimolar Reaction / ${ }^{13} \mathrm{C}$ NMR / Gas Chromatography-Mass Spectrometry /
\end{abstract}

In the course of our study, we found that acrolein oxime (AOM) could be polymerized thermally, catalytically and by $\gamma$-irradiation. ${ }^{1-6}$ An anionic mechanism was operative in the thermal polymerization. ${ }^{1}$ The polymerization by butyllithium (BuLi) showed different time-conversion curves depending on the kind of solvent used. ${ }^{3}$ It is probable that some initiating species are formed in the reaction of AOM with BuLi. In order to elucidate the initiation step of the polymerization, an equimolar reaction of these compounds was conducted in different solvents, and the structure of the resulting products was confirmed or presumed by ${ }^{13} \mathrm{C}-\mathrm{NMR}$ (CMR) spectroscopy and gas chromatography-mass spectrometry (GC-MS).

\section{EXPERIMENTAL}

\section{Materials}

AOM was prepared according to the method described previously; ${ }^{7}$ bp $44^{\circ} \mathrm{C}(14 \mathrm{mmHg})$. Heptanal oxime (HPOM, 1) was obtained by oximation of heptylaldehyde under conditions similar to the preparation of $\mathrm{AOM} ; \mathrm{mp} 54-55^{\circ} \mathrm{C}$.

\section{Equimolar Reaction of $\mathrm{AOM}$ and BuLi}

In a $100 \mathrm{ml}$ Erlenmeyer flask with a rubber stopper were placed $30 \mathrm{ml}$ of solvent and $10 \mathrm{ml}$ of hexane containing $0.0159 \mathrm{~mol}$ of BuLi. The solution was kept at $0^{\circ} \mathrm{C}$ and then $1 \mathrm{ml}(0.013 \mathrm{~mol})$ of $\mathrm{AOM}$, if necessary, $2 \mathrm{ml}$ of equivolume mixture of AOM and solvent, were injected through the stopper. Stirred for $30 \mathrm{~min}$, the contents were then poured into a large amount of ether. The ether was shaken with $1 N$ hydrochloric acid, whereupon the aqueous layer was brought to $\mathrm{pH}=7$, and then separated. The products were obtained by removal of the ether under reduced pressure.

\section{Equimolar Reaction of HPOM and BuLi}

$500 \mathrm{mg}\left(3.88 \times 10^{-3} \mathrm{~mol}\right)$ of HPOM in $10 \mathrm{ml}$ of hexane were added at $0^{\circ} \mathrm{C}$ to $3 \mathrm{ml}$ of hexane containing $4.78 \times 10^{-3} \mathrm{~mol}$ of $\mathrm{BuLi}$, followed by treatments similar to the above. The products obtained were fractionated by gas chromatography; silicon OV-17 (5\%) supported on Gaschrom $Q$ was used as the stationary phase. 


\section{GC-MS Measurements}

Spectra were determined with a Shimadzu LKB9000 mass spectrometer, equipped with a gas chromatographic inlet system. The ionizing potential was $70 \mathrm{eV}$ and the ionizing current was $60 \mu \mathrm{A}$. An FID trace was performed with a Shimadzu GC-7A under identical chromatographic conditions.

\section{CMR Measurements}

Spectra were obtained with a Hitachi R-42 FT $(22.6 \mathrm{MHz})$ at $35^{\circ} \mathrm{C}$, using tetramethylsilane (TMS) as the internal standard and deuterated chloroform $\left(\mathrm{CDCl}_{3}\right)$ as the solvent. The concentrations were $16.7 \%$ (HPOM) and $8.3 \%$ [butyl hexyl ketone oxime (BHOM, 2)].

\section{RESULTS AND DISCUSSION}

The equimolar reaction of $\mathrm{AOM}$ and $\mathrm{BuLi}$ was carried out at $0^{\circ} \mathrm{C}$ for $30 \mathrm{~min}$ in hexane, dichloroethane (DCE) and tetrahydrofuran (THF) solutions. The unreacted AOM was determined by means of gas chromatograph with and then without treatment with $1 N$ hydrochloric acid. It can be seen from Table I that in every system a large portion of AOM is converted into lithium acrolein oxime as soon as it is mixed with $\mathrm{BuLi}$ and that $\mathrm{AOM}$ is recovered in a $70-80 \%$ yield by the treatment of the reaction mixture with dilute acid. When AOM was polymerized in the presence of hydrochloric acid, no water served as an inhibitor. ${ }^{4}$ Thus, polymerization may occur during the course of the treatment with dilute acid.

The CMR spectrum of the reaction mixture untreated with hydrochloric acid had peaks at $120.31,133.41$, and $153.44 \mathrm{ppm}$, but no peaks coincided in position with those of AOM (124.14, 130.93 , and $152.10 \mathrm{ppm}$ for the syn form, and 125.36 , 125.63 , and $149.00 \mathrm{ppm}$ for the anti form). When

Table I. Equimolar reaction of $\mathrm{AOM}$ and $\mathrm{BuLi}^{\mathrm{a}}$

\begin{tabular}{|c|c|c|c|}
\hline & \multicolumn{3}{|c|}{$\mathrm{AOM}^{\mathrm{b}}$ in the reaction mixture $/ \%$} \\
\hline & Hexane & DCE & THF \\
\hline Before treatment & trace & 2.9 & 2.8 \\
\hline After treatment $^{\mathrm{c}}$ & 70 & 80 & 75 \\
\hline
\end{tabular}

a The reaction was carried out at $0^{\circ} \mathrm{C}$ for $30 \mathrm{~min}$.

b Percentage of AOM recovered.

c The reaction mixture was treated with $1 \mathrm{~N} \mathrm{HCl}$.
AOM was mixed with equimolar lithium hydroxide in aqueous media, respective carbons of AOM also resonated at different magnetic fields from the original ones. ${ }^{6}$ It was concluded that movement from AOM $\left(\mathrm{CH}_{2}=\mathrm{CH}-\mathrm{CH}=\mathrm{N}-\mathrm{OH}\right)$ to lithium acrolein oxime $\left(\mathrm{CH}_{2}=\mathrm{CH}-\mathrm{CH}=\mathrm{N}-\mathrm{O}^{\ominus} \cdots \mathrm{Li}^{\oplus}\right)$ causes a shift in the signals of the respective carbons. Thus AOM and BuLi mainly undergo acid-base reaction, and the resulting lithium acrolein oxime $\left(\mathrm{AOM}^{\ominus}\right.$ $\left.\cdots \mathrm{Li}^{\oplus}\right)$ is converted to $\mathrm{AOM}$ by neutralization with dilute hydrochloric acid.

$$
\begin{aligned}
& \mathrm{AOM}+\mathrm{BuLi} \longrightarrow \\
& \mathrm{CH}_{2}=\mathrm{CH}-\mathrm{CH}=\mathrm{N}-\mathrm{O}^{\ominus} \cdots \mathrm{Li}^{\oplus}+\mathrm{C}_{4} \mathrm{H}_{10} \\
& \quad\left(\mathrm{AOM}^{\ominus} \cdots \mathrm{Li}^{\oplus}\right) \\
& \mathrm{AOM}^{\ominus} \cdots \mathrm{Li}^{\oplus}+\mathrm{HCl} \longrightarrow \mathrm{AOM}+\mathrm{LiCl}
\end{aligned}
$$

A part of the BuLi and the lithium acrolein oxime can add to vinyl group or oxime group of the unreacted AOM. The BuLi serves as butyl anion. This addition reaction leads to several products. Figure 1 shows FID trace of the reaction mixture treated with dilute acid. For simplification, the products corresponding to the respective peaks are given the symbols $\mathbf{A}, \mathbf{B}, \mathbf{C}, \ldots$ The reaction mixture
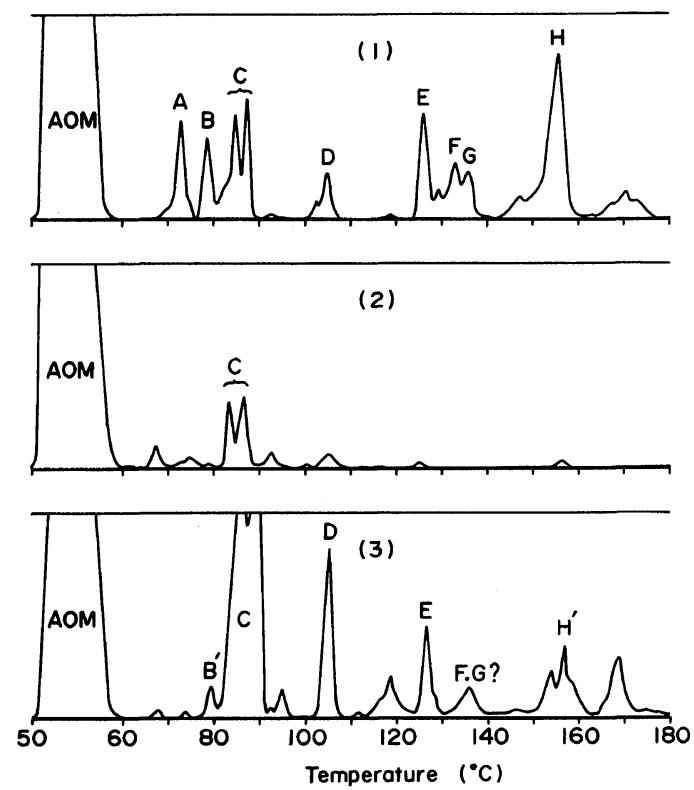

Figure 1. Gas chromatograms of reaction mixture in hexane (1), DCE (2), and THF (3). 
was subjected to GC-MS measurements in order to determine the structure of the respective products.

Compound $\mathbf{C}$ contains two components, both of which give similar fragmentation of the mass spectra, i.e., this compound is a mixture of two isomers, the syn and anti forms. Compound $\mathbf{C}$ was identified as $\mathbf{1}$ by comparing the mass spectrum with that of previously obtained authentic sample. Table II shows the molar ratio of $\mathbf{1}$ to the recovered AOM. This ratio was calculated from the area obtained by integration of the GC peaks. In the reaction in the THF solution, relatively large amounts of 1 are formed by the addition of the butyl anion to the $\beta$ carbon of the vinyl groups in AOM and lithium acrolein oxime.

Table II. Ratio of HPOM obtained to AOM recovered $^{\mathrm{a}}$

\begin{tabular}{cccc}
\hline & \multicolumn{3}{c}{$\begin{array}{c}\text { Molar ratio of HPOM to AOM } \\
\text { in the reaction mixture }\end{array}$} \\
\cline { 2 - 4 } & Hexane & DCE & THF \\
\hline AOM : HPOM & $1: 0.02$ & $1: 0.01$ & $1: 0.06$
\end{tabular}

a The equimolar reaction of $\mathrm{AOM}$ and $\mathrm{BuLi}$ was carried out at $0^{\circ} \mathrm{C}$ for $30 \mathrm{~min}$, and then the reaction mixture was treated with $1 \mathrm{~N} \mathrm{HCl}$.

$$
\begin{aligned}
& (\mathrm{BuLi})_{n} \rightleftarrows \mathrm{Bu}^{\ominus} \ldots \mathrm{Li}^{\oplus}
\end{aligned}
$$

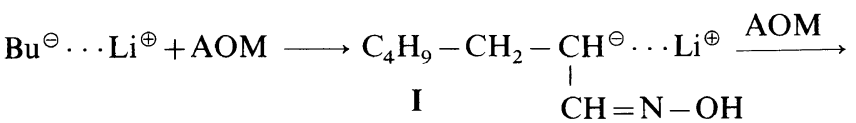

$$
\begin{aligned}
& \mathrm{C}_{6} \mathrm{H}_{13}-\mathrm{CH}=\mathrm{N}-\mathrm{OH} \\
& 1 \\
& \begin{aligned}
\mathrm{Bu}^{\ominus} \cdots \mathrm{Li}^{\oplus}+\mathrm{AOM}^{\ominus} \cdots \mathrm{Li}^{\oplus} \longrightarrow \mathrm{C}_{4} \mathrm{H}_{9}-\mathrm{CH}_{2}-\underset{!}{\mathrm{CH}^{\ominus}} \cdots \mathrm{Li}^{\oplus} \\
\mathrm{CH}=\mathrm{N}-\mathrm{O}^{\ominus} \cdots \mathrm{Li}^{\oplus}
\end{aligned} \\
& \underset{\mathrm{HCl}}{\stackrel{\mathrm{AOM}}{\rightarrow}} \mathbf{1}+\mathrm{AOM}^{\ominus} \cdots \mathrm{Li}^{\oplus}+\mathrm{LiCl}
\end{aligned}
$$

When synthesized syn-heptanal oxime is allowed to stand in solution for a long time, isomerization occurs. The anti form is eluted at a lower retention temperature and follows by the syn form.

Figure 2(2) shows the mass spectrum of compound E. For the identification, the equimolar reactionof 1 and $\mathrm{BuLi}$ was carried out at $0^{\circ} \mathrm{C}$. Several compounds are obtained in the reaction. The main product was fractionated by means of gas chromatography. The NMR spectrum of the fractionated product is shown in Figure 3, where appear peaks corresponding to methyl, methylene and quarternary carbons, particularly singlet peak at 161.99 ppm reveals a ketone, i.e., butyl hexyl ketone oxime (2). Compound $\mathbf{E}$ agrees with 2 in the chromatographic retention temperature and in the fragmentation of the mass spectrum. Thus compound $\mathbf{E}$ is identified as $\mathbf{2}$, which may be formed by the addition of butyl anion to the oxime group in $\mathbf{1}$ and by the subsequent elimination of lithium hydride.

$$
\begin{aligned}
& \mathbf{1}+\mathrm{Bu}^{\ominus} \cdots \mathrm{Li}^{\oplus} \longrightarrow \underset{\mathrm{II}}{\mathrm{C}_{4} \mathrm{H}_{9}}-\mathrm{CH}_{\mathbf{I}}^{\mathrm{C}_{6} \mathrm{H}_{13}} \mathrm{~N}_{\mathrm{OH}}^{\ominus} \ldots \mathrm{Li}^{\oplus} \\
& \stackrel{-\mathrm{LiH}}{\longrightarrow} \mathrm{C}_{4} \mathrm{H}_{9}-\mathrm{C}=\mathrm{N}-\mathrm{OH} \\
& 2
\end{aligned}
$$

The formation of $\mathbf{2}$ from $\mathbf{1}$ suggests that butyl vinyl ketone oxime (3) is also formed from AOM according to the following equation.

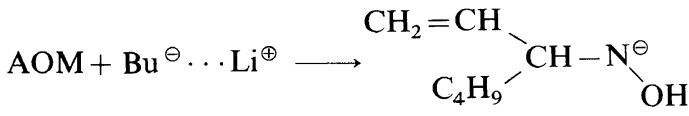

$$
\begin{aligned}
& \text { III } \\
& \cdots \mathrm{Li}^{\oplus} \stackrel{-\mathrm{LiH}}{\longrightarrow}
\end{aligned}
$$


T. Ota, M. Tanaka, Y. Asahi, and S. Masuda

$$
\begin{aligned}
& \mathrm{CH}_{2}=\mathrm{CH} \\
& \mathrm{C}_{4} \mathrm{H}_{9} \\
& \mathrm{C}=\mathrm{N}-\mathrm{OH}
\end{aligned}
$$

\section{3}

The mass spectrum of compound $\mathbf{B}$ shown in Figure 2(3) suggests 3 , which is characterized by the appearance of peaks $m / e=127$ (molecular ion), 85
(McLafferty rearrangement), and 84 ( $\beta$-cleavage). Compound $\mathbf{B}$ is obtained in significant quantities in the reaction in hexane, but in little of yield in DCE and THF (this is no denying of possibility of the reaction). As shown in Figure 4(1), compound $\mathbf{B}^{\prime}$ is different from compound $\mathbf{B}$ in the fragmentation of the mass spectrum, though both have the same

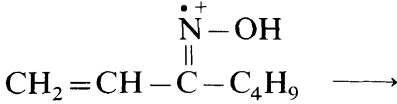

$$
\begin{aligned}
& \text { m/e } 127
\end{aligned}
$$

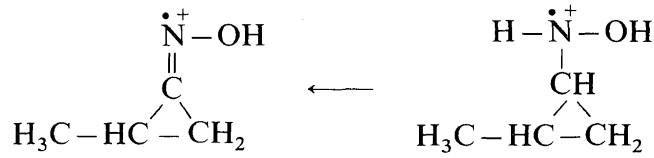

$$
\begin{aligned}
& \begin{array}{c}
\downarrow \\
\mathrm{H}-\dot{\mathrm{N}}^{+}-\mathrm{OH} \\
\mathrm{CH}_{2}=\mathrm{CH}-\mathrm{C}=\mathrm{CH}_{2} \\
m / e 85
\end{array} \\
& \begin{array}{c}
m / e 85 \\
{\left[\begin{array}{c}
\mathrm{H}-\mathrm{N}-\mathrm{OH} \\
1 \\
\mathrm{CH}_{2}=\mathrm{CH}-\mathrm{CH}-\mathrm{C}_{4} \mathrm{H}_{9}
\end{array}\right]^{+} \text {m/e } 129}
\end{array} \\
& \begin{array}{c}
\downarrow \\
\mathrm{H}-\dot{\mathrm{N}}^{+}-\mathrm{OH} \\
\mathrm{CH}_{2}=\mathrm{CH}-\mathrm{C}=\mathrm{CH}_{2} \\
m / e 85
\end{array} \\
& \begin{array}{c}
\downarrow \\
\mathrm{H}-\dot{\mathrm{N}}^{+}-\mathrm{OH} \\
\mathrm{CH}_{2}=\mathrm{CH}-\mathrm{C}=\mathrm{CH}_{2} \\
m / e 85
\end{array} \\
& m / e 87 \\
& \begin{array}{c}
\mathrm{H}-\dot{\mathrm{N}}^{+}-\mathrm{H} \\
\mathrm{CH}_{2}=\mathrm{CH}-\mathrm{C}=\mathrm{CH}_{2} \\
\text { m/e } 69
\end{array}
\end{aligned}
$$

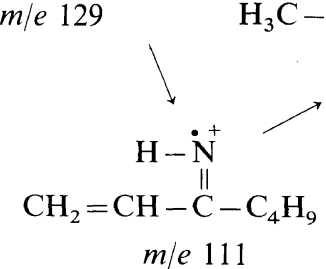

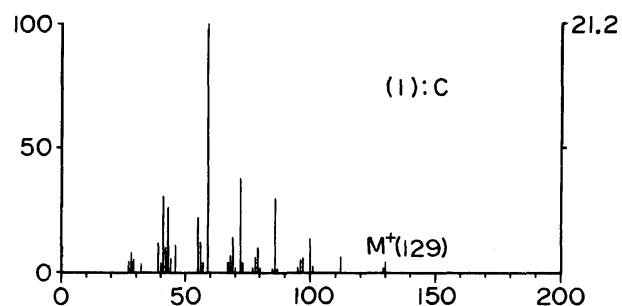
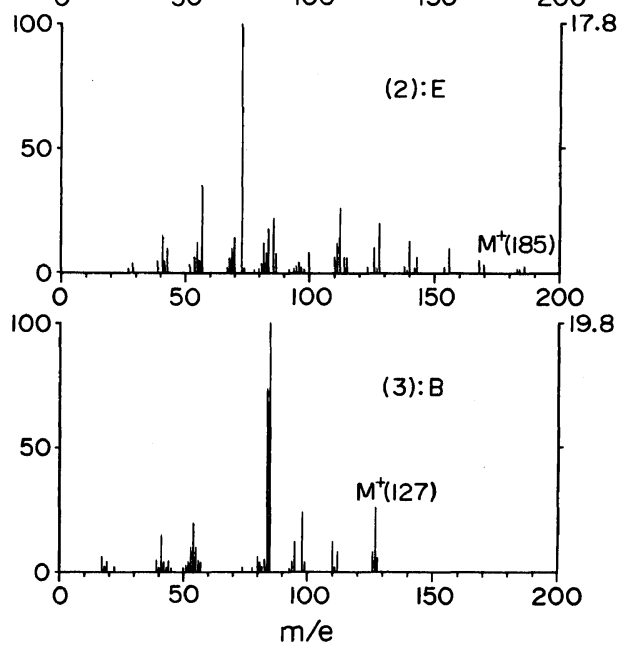

retention temperature. When $N$-1-vinylpentylhydroxylamine (4) is assumed as compound $\mathbf{B}^{\prime}$, the mass spectrum can be satisfactorily explained on the basis of the following fragmentation pattern.

Compound $\mathbf{B}^{\prime}$ may be formed according to eq 7 . Intermediate [II] is supposed to give $N$-1-butylheptylhydroxylamine (5) by the similar reaction. However, the formation of $\mathbf{5}$ could not be comfirmed by GC-MS measurement.

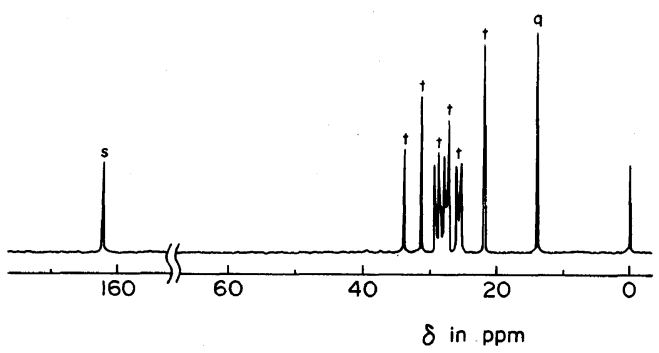

Figure 3. CMR spectrum of BHOM.

Figure 2. Mass spectra: (1), compound C; (2), compound $\mathbf{E}$; (3), compound $\mathbf{B}$. 
$\mathrm{CH}_{2}=\mathrm{CH}_{4} \mathrm{H}_{9}^{\prime} \mathrm{CH}-\mathrm{NH}_{\mathrm{OH}}^{\ominus} \ldots \mathrm{Li}^{\oplus} \frac{\mathrm{AOM}}{\text { or } \mathrm{HCl}}$

III

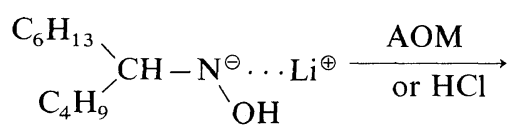

II
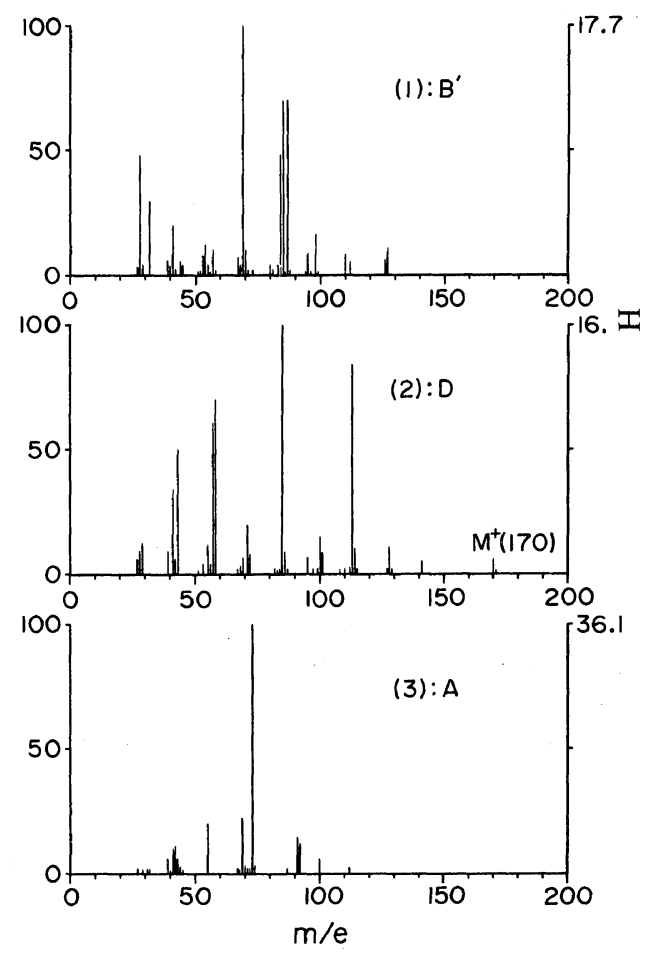

Figure 4. Mass spectra: (1), compound $\mathbf{B}^{\prime} ;(2)$, compound D; (3), compound A.

$$
\begin{aligned}
& \mathrm{CH}_{2}=\mathrm{CH} \\
& \begin{array}{c}
\mathrm{C}_{4} \mathrm{H}_{9}^{\prime} \mathrm{CH}-\mathrm{NH}-\mathrm{OH}+\mathrm{AOM}^{\ominus} \cdots \mathrm{Li}^{\oplus} \\
\text { (or } \mathrm{LiCl} \text { ) }
\end{array}
\end{aligned}
$$

$$
4
$$

$$
\begin{gathered}
\mathrm{C}_{6} \mathrm{H}_{13} \\
\mathrm{C}_{4} \mathrm{H}_{9}
\end{gathered} \mathrm{CH}-\mathrm{NH}-\mathrm{OH}+\underset{\text { (or } \mathrm{LiCl}^{\prime}}{\mathrm{AOM}^{\ominus}}
$$

\section{5}

The mass spectrum of compound $\mathbf{D}$ shown in Figure 4(2) demonstrates that the molecular ion $m / e=170$ is lost either as a neutral fragment or as a radical fragment in the formation of species of mass $128,113,100,85,58$, and 57 . This fragmentation shows the typical cleavage of a ketone (the elimination of carbon monoxide and the double McLafferty rearrangement), i.e., butyl hexyl ketone (6), which may be formed according to eq 9. A similar reaction, the formation of butyl vinyl ketone from intermediate [III], can be expected, but evidence for this is lacking.

$$
\begin{aligned}
& \text { [II] } \underset{\text { or } \mathrm{HCl}}{\stackrel{\mathrm{AOM}}{\longrightarrow}} 5 \stackrel{-\mathrm{H}_{2} \mathrm{O}}{\longrightarrow} \stackrel{\mathrm{C}_{6} \mathrm{H}_{13}}{\mathrm{C}_{4} \mathrm{H}_{9}^{\prime}}-\mathrm{C}=\mathrm{NH}
\end{aligned}
$$

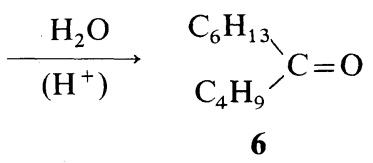

The mass spectrum of compound $\mathbf{A}$ shown in Figure 4(3) has base ion peak $m / e=73$ though no molecular ion peak appears and suggests 2methylhexanal oxime (7). Thus, the addition of the butyl anion to the $\alpha$-carbon of the vinyl group seems to be possible contrary to the stability of the resulting carbanion.

$$
\begin{aligned}
& \mathrm{AOM}+\mathrm{Bu}^{\ominus} \cdots \mathrm{Li}^{\oplus} \longrightarrow \begin{array}{c}
\mathrm{C}_{4} \mathrm{H}_{9}-\underset{l}{\mathrm{CH}}-\mathrm{CH}_{2}{ }^{\ominus} \cdots \mathrm{Li}^{\oplus} \\
\mathrm{CH}=\mathrm{N}-\mathrm{OH}
\end{array} \frac{\mathrm{AOM}}{\text { or } \mathrm{HCl}} \\
& \begin{array}{r}
\mathrm{C}_{4} \mathrm{H}_{9}-\underset{\text { l }}{\mathrm{CH}}-\mathrm{CH}_{3} \\
\mathrm{CH}=\mathrm{N}-\mathrm{OH} \quad+\mathrm{AOM}^{\ominus} \ldots \mathrm{Li}^{\oplus} \\
\text { (or } \mathrm{LiCl} \text { ) }
\end{array} \\
& 7 \\
& \mathrm{AOM}^{\ominus} \cdots \mathrm{Li}^{\oplus}+\mathrm{Bu}^{\ominus} \cdots \mathrm{Li}^{\oplus} \longrightarrow \mathrm{C}_{4} \mathrm{H}_{9}-\underset{l}{\mathrm{CH}}-\mathrm{CH}_{2}{ }^{\ominus} \cdots \mathrm{Li}^{\oplus} \quad \stackrel{\mathrm{AOM}}{\longrightarrow} \\
& \begin{aligned}
& \mathrm{C}_{4} \mathrm{H}_{9}-\underset{l}{\mathrm{CH}}-\mathrm{CH}_{3} \\
& \mathrm{CH}=\mathrm{N}-\mathrm{O}^{\ominus} \ldots \mathrm{Li}^{\oplus}
\end{aligned}+\mathrm{AOM}^{\ominus} \cdots \mathrm{Li}^{\oplus} \frac{\mathrm{AOM}}{\mathrm{HCl}}
\end{aligned}
$$




$$
\begin{aligned}
\mathrm{C}_{4} \mathrm{H}_{9}-\underset{l}{\mathrm{C}} \mathrm{H}-\mathrm{CH}_{3} \\
\mathrm{CH}=\mathrm{N}-\mathrm{OH}
\end{aligned}
$$

7

The butyl anion makes a further attack on the oxime group in the resulting 7 to give butyl 1-methylpentyl ketone oxime (8) and 1-butyl-2-methylhexylhydroxylamine (9). The mass spectra of compounds $\mathbf{F}$ and $\mathbf{G}$ give similar fragmentation to each other, though base ion peaks appear at $m / e=55$ and 57 , respectively. It is assumed on the basis of the mass fragmentation that these two compounds are mixture of $\mathbf{8}$ and $\mathbf{9}$, respectively.

$$
\begin{aligned}
& \mathrm{C}_{4} \mathrm{H}_{9}-\underset{I}{\mathrm{C}} \mathrm{H}-\mathrm{CH}_{3} \\
& \stackrel{\mathrm{C}}{\mathbf{2}}=\mathrm{N}-\mathrm{OH} \\
& \mathrm{C}_{4} \mathrm{H}_{9}-\underset{\mathrm{C}}{\mathrm{C}}-\mathrm{CH}_{3}+\mathrm{BiH} \quad \mathrm{Bu}^{\ominus} \cdots \mathrm{Li}^{\oplus} \\
& \mathrm{C}_{4} \mathrm{H}_{9}-\mathrm{C}=\mathrm{N}-\mathrm{OH}
\end{aligned}
$$

8

is difficult to determine the structure of the compounds only by GC-MS measurement.

The compounds which are formed or which may be formed by the equimolar reaction are summarized in Table III. Though, in the strict sense, the equimolar reaction would not give the same products as does the reaction of AOM with a catalytic amount of $\mathrm{BuLi}$, the above-described results qualitatively support the conclusion ${ }^{3}$ that AOM serves mainly as an acid to produce lithium acrolein oxime in the reaction with $\mathrm{BuLi}$ and that the resulting lithium acrolein oxime can initiate the polymerization. It was concluded in our previous paper ${ }^{3}$ that $\mathrm{BuLi}$ catalyzed polymerization of AOM proceeds through an initiation step by the reaction of a monomer and catalyst, each of which has a different aggregation factor depending on the kind of solvent used: When the polymerization of AOM was carried out in the DCE solution in the presence of $\mathrm{BuLi}$, a plot of time against conversion gave a straight line up to high conversions $(<70 \%)$. This fact explains that AOM and $\mathrm{BuLi}$ are in the aggregation form, mainly in the form of the dimer and trimer, and in the monomeric form, respectively, and that BuLi reacts very rapidly with $\mathrm{AOM}$ to give lithium acrolein oxime, by which the polymerization is initiated rather than by butyl anion. On the other hand, both AOM and BuLi in THF are in the monomeric form. In such a system,

$$
\begin{gathered}
+\mathrm{AOM}^{\ominus} \cdots \mathrm{Li}^{\oplus} \\
(\text { or } \mathrm{LiCl})
\end{gathered}
$$

The above-described is concerned with the process of the formation of products having one unit of AOM. From the fragmentations of other mass spectra, a further assumption can be made that AOM makes a further attack on the intermediates [I]--[IV] to give the compounds having two or more units of AOM. In fact, there are several compounds having higher retention temperature in the gas chromatogram of the reaction mixture. However, it

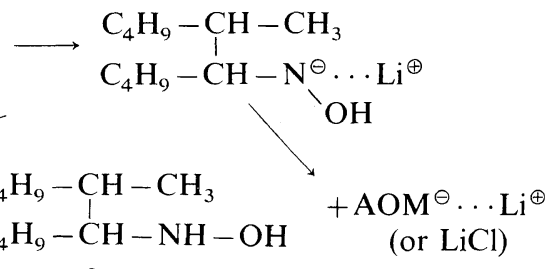

$$
9
$$

BuLi reacts with $A O M$ according to eq 1 , but the initiation by butyl anion can not be negligible. Consequently, the polymerization is extremely fast at the initial stage but afterwards, proceeds at a constant rate. The formation of a relatively large amount of $\mathbf{1}$ in the equimolar reaction supports the description for the polymerization in the THF solution.

Since BuLi was used as a hexane solution, the equimolar reaction could not be performed under conditions of no solvent. The rate of the AOM polymerization in hexane solution is proportional to the 0.8 th power of the concentration of BuLi (the reaction order with respect to the concentration of BuLi is 0.5 in bulk, and 1.0 in DCE and in $\mathrm{THF}^{3}$ ). Since only monomeric BuLi can react with AOM, the acceleration of the reaction was initially observed in the bulk polymerization. The equimolar reaction in hexane gives many products.

In anionic polymerization, the active species was hitherto considered to attack the $\beta$-carbon of vinyl group. However, the results of the equimolar reaction require that the addition to the $\alpha$-carbon and the oxime group, other than the $\beta$-addition (head addition), is take into account. The addition to oxime group leads to 3,4-addition structure having a pendant vinyl group. Therefore, though the ratio of the 1,4-addition and the 1,4-hydrogen transfer struc- 
Table III. Reaction products ${ }^{\mathrm{a}}$

\begin{tabular}{|c|c|c|c|c|}
\hline \multirow{2}{*}{ Compound } & \multirow{2}{*}{ Structure } & \multicolumn{3}{|c|}{ Solvent } \\
\hline & & Hexane & DCE & THF \\
\hline $\begin{array}{c}\text { A } \\
(\mathrm{MHOM}) \\
7\end{array}$ & $\begin{array}{c}\mathrm{CH}_{3}-\mathrm{CH}-\mathrm{C}_{4} \mathrm{H}_{9} \\
\mid \\
\mathrm{CH}=\mathrm{N}-\mathrm{OH}\end{array}$ & + & - & - \\
\hline $\begin{array}{c}\text { B } \\
(\mathrm{BVOM}) \\
\mathbf{3}\end{array}$ & $\begin{array}{l}\mathrm{CH}_{2}=\mathrm{CH} \\
\mathrm{C}_{4} \mathrm{H}_{9}-\mathrm{C}=\mathrm{N}-\mathrm{OH}\end{array}$ & + & - & - \\
\hline $\begin{array}{c}\mathbf{B}^{\prime} \\
(\mathrm{VPHA}) \\
\mathbf{4}\end{array}$ & $\begin{array}{l}\mathrm{CH}_{2}=\mathrm{CH} \\
\mathrm{C}_{4} \mathrm{H}_{9}-\mathrm{CH}-\mathrm{NH}-\mathrm{OH}\end{array}$ & - & - & + \\
\hline $\begin{array}{c}\mathbf{C} \\
(\mathrm{HPOM}) \\
\mathbf{1}\end{array}$ & $\begin{array}{c}\mathrm{C}_{4} \mathrm{H}_{9}-\mathrm{CH}_{2}-\mathrm{CH}_{2} \\
\mathrm{HO}-\mathrm{N}=\mathrm{CH}\end{array}$ & + & + & + \\
\hline $\begin{array}{c}\text { D } \\
(\mathrm{BHK}) \\
6\end{array}$ & $\begin{array}{r}\mathrm{C}_{4} \mathrm{H}_{9}-\mathrm{CH}_{2}-\mathrm{CH}_{2} \\
\mathrm{C}_{4} \mathrm{H}_{9}-\mathrm{C}=\mathrm{O}\end{array}$ & + & - & + \\
\hline $\begin{array}{c}\mathbf{E} \\
(\mathrm{BHOM}) \\
\mathbf{2}\end{array}$ & $\begin{aligned} & \mathrm{C}_{4} \mathrm{H}_{9}-\mathrm{CH}_{2}-\mathrm{CH}_{2} \\
& ! \\
& \mathrm{C}_{4} \mathrm{H}_{9}-\mathrm{C}=\mathrm{N}-\mathrm{OH}\end{aligned}$ & + & - & + \\
\hline $\begin{array}{c}\text { F and } \mathbf{G} \\
(\mathrm{BMPOM}) \\
\mathbf{8} \\
(\mathrm{BMHHA}) \\
\mathbf{9}\end{array}$ & $\begin{array}{l}\mathrm{C}_{4} \mathrm{H}_{9}-\mathrm{CH}-\mathrm{CH}_{3} \\
\mathrm{C}_{4} \mathrm{H}_{9}-\mathrm{C}=\mathrm{N}-\mathrm{OH} \\
\mathrm{C}_{4} \mathrm{H}_{9}-\mathrm{CH}-\mathrm{CH}_{3} \\
\mathrm{C}_{4} \mathrm{H}_{9}-\mathrm{CH}-\mathrm{NH}-\mathrm{OH}\end{array}$ & + & - & - \\
\hline
\end{tabular}

a + , detectable; - , undetectable.

The equimolar reaction of AOM and BuLi was carried out in different solvents. tural units to the overall structural units has been calculated by determining the content of carbon-carbon double bonds, the 3,4-addition and the 3,4-hydrogen transfer structures must be considered in the strict sense. When the anion species adds to the oxime group, the subsequent elimination reaction of lithium hydride is not a termination reaction since reinitiation occurs.

$$
\mathrm{AOM}+\mathrm{LiH} \longrightarrow \mathrm{AOM}^{\ominus} \ldots \mathrm{Li}^{\oplus}+\mathrm{H}_{2}
$$

In the THF solution, 6 is produced in relatively larger quantities and no measurable amount of $\mathbf{3}$ is obtained. Probably, the elimination of lithium hydride scarecely occurs because of the highly freeionic character of intermediate [III].

\section{REFERENCES}

1. S. Masuda and T. Ota, Polym. J., 9, 459 (1977).

2. S. Masuda and T. Ota, Polym. J., 9, 465 (1977).

3. S. Masuda, M. Tanaka, and T. Ota, Polym. J., 10, 387 (1978).

4. S. Masuda and T. Ota, Polym. J., 10, 398 (1978).

5. S. Masuda and H. Tamai, M. Torii, M. Tanaka, and T. Ota, Polym. J., 11, 213 (1979).

6. S. Masuda, Y. Matsunaga, and T. Ota, Kobunshi Ronbushu, 36, 437 (1979).

7. S. Masuda, H. Kihara, and T. Ota, Nippom Kagaku Kaishi, 608 (1974). 